\title{
Solubilization of $\mathrm{Na}$,K-ATPase from rabbit kidney outer medulla using only $\mathrm{C}_{12} \mathrm{E}_{8}$
}

H.L. Santos,

R.P. Lamas and

P. Ciancaglini
Departamento de Química, Faculdade de Filosofia, Ciências e Letras de Ribeirão Preto, U niversidade de São Paulo, Ribeirão Preto, SP, Brasil

\section{Correspondence \\ P. Ciancaglini \\ Departamento de Química \\ FFCLRP, USP \\ Av. Bandeirantes, 3900 \\ 14040-901 Ribeirão Preto, SP \\ Brasil \\ Fax: + 55-16-633-8151 \\ E-mail: pietro@ffclrp.usp.br \\ Research supported by FAPESP and CNPq. H.L. Santos is the recipient \\ of a student fellowship from \\ FAPESP, and P. Ciancaglini is a \\ $\mathrm{CNPq}$ research fellow.}

Received April 20, 2001

Accepted January 2, 2002

\section{Abstract}

SDS, $\mathrm{C}_{12} \mathrm{E}_{8}$, CHAPS or CHAPSO or a combination of two of these detergents is generally used for the solubilization of $\mathrm{Na}, \mathrm{K}-\mathrm{ATP}$ ase and other ATPases. Our method using only $\mathrm{C}_{12} \mathrm{E}_{8}$ has the advantage of considerable reduction of the time for enzyme purification, with rapid solubilization and purification in a single chromatographic step. $\mathrm{Na}, \mathrm{K}-$ ATPase-rich membrane fragments of rabbit kidney outer medulla were obtained without adding SDS. Optimum conditions for solubilization were obtained at $4^{\circ} \mathrm{C}$ after rapid mixing of $1 \mathrm{mg}$ of membrane $\mathrm{Na}, \mathrm{K}$-ATPase with $1 \mathrm{mg}$ of $\mathrm{C}_{12} \mathrm{E}_{8} / \mathrm{ml}$, yielding $98 \%$ recovery of the activity. The solubilized enzyme was purified by gel filtration on a Sepharose $6 \mathrm{~B}$ column at $4^{\circ} \mathrm{C}$. Non-denaturing PAGE revealed a single protein band with phosphomonohydrolase activity. The molecular mass of the purified enzyme estimated by gel filtration chromatography was $320 \mathrm{kDa}$. The optimum apparent $\mathrm{pH}$ obtained for the purified enzyme was 7.5 for both PNPP and ATP. The dependence of ATPase activity on ATP concentration showed high $\left(K_{0.5}=4.0 \mu \mathrm{M}\right)$ and low $\left(K_{0.5}=1.4 \mathrm{mM}\right)$ affinity sites for ATP, with negative cooperativity. Ouabain $(5 \mathrm{mM})$, oligomycin $(1 \mu \mathrm{g} / \mathrm{ml})$ and sodium vanadate $(3 \mu \mathrm{M})$ inhibited the ATPase activity of $\mathrm{C}_{12} \mathrm{E}_{8}$-solubilized and purified $\mathrm{Na}, \mathrm{K}$ ATPase by 99,81 and $98.5 \%$, respectively. We have shown that $\mathrm{Na}, \mathrm{K}-$ ATPase solubilized only with $\mathrm{C}_{12} \mathrm{E}_{8}$ can be purified and retains its activity. The activity is consistent with the form of $(\alpha \beta)_{2}$ association.

\section{Introduction}

Detergents have been successfully used for the solubilization of membrane proteins. Several excellent reviews can be found on use in the solubilization of membrane proteins (1-4). Due to three important factors, non-ionic detergents are frequently used for the solubilization of protein membranes: i) detergents, their physical properties and their

\section{Key words}

- $\mathrm{Na}$,K-ATPase

- Rabbit kidney medulla

- Membrane solubilization

- $\mathrm{C}_{12} \mathrm{E}_{8}$

- $(\alpha \beta)_{2}$ Dimer 
and/or Na,K-ATPase solubilization, although it partially denatures the enzyme molecule, is sodium dodecyl sulfate (SDS). Other detergents that have also been used to inactivate the enzyme in a concentration-dependent way are cholate, deoxycholate and 3-((3cholamidopropyl)dimethylamino)-1-propane sulfonate (CHAPS) (7). For example, sodium cholate $(1-2 \%, \mathrm{w} / \mathrm{v})$ solubilizes $50 \%$ of renal $\mathrm{Na}, \mathrm{K}-\mathrm{ATPa} e$ with retention of only half of the original specific activity (7). On the other hand, $0.2 \%(\mathrm{w} / \mathrm{v})$ deoxycholate combined with $0.1 \%(\mathrm{w} / \mathrm{v})$ saponin and high concentrations of $\mathrm{NaCl}(\sim 360 \mathrm{mM})$ and cholesterol was efficient in Na,K-ATPase solubilization without losses of specific activity $(7,8)$. However, CHAPS when used at a 1:2 $(\mathrm{w} / \mathrm{w})$ ratio of detergent:enzyme at a final concentration of $9 \mathrm{mM}(0.55 \%, \mathrm{w} / \mathrm{v})$ solubilized about $25 \%$ of the enzyme without loss of specific activity (7).

Another class of detergents used in $\mathrm{Na}, \mathrm{K}-$ ATPase solubilization are octylglucosides and polyoxyethylenes (Triton, Lubrol, Brij, dodecyloctaethyleneglycol $\left(\mathrm{C}_{12} \mathrm{E}_{8}\right)$ and Tween). Octylglucoside was not efficient for Na,K-ATPase solubilization because it needed a long incubation time with the protein, with the consequent inactivation of the enzyme. In contrast, polyoxyethylenes are good agents for $\mathrm{Na}$,K-ATPase solubilization (7). Triton X-100, when used at a concentration of $0.25 \%(\mathrm{w} / \mathrm{v})$, solubilizes $92 \%$ of $\mathrm{Na}, \mathrm{K}$ ATPase from kidney outer medulla, but partially inactivates the reconstituted enzyme (9).

A detergent that has been used with great success in $\mathrm{Na}, \mathrm{K}-\mathrm{ATPase}$ solubilization is $\mathrm{C}_{12} \mathrm{E}_{8}(4,5,7,10,11)$. Different results showed that $\mathrm{Na}, \mathrm{K}-\mathrm{ATPase}$ previously treated with SDS can be solubilized with $\mathrm{C}_{12} \mathrm{E}_{8}$ in an active form where most of the kinetic and conformational properties of the enzyme are preserved after solubilization $(4,7,11)$.

$\mathrm{Na}, \mathrm{K}-\mathrm{ATP}$ ase is an integral membrane protein found in all superior eukaryotic cells which are responsible for the active trans- port of sodium and potassium ions through the plasma membrane coupled with ATP hydrolysis $(8,12-14)$. This enzyme is a heterodimer of three subunits: $\alpha$ subunit, with a molecular mass of about $110 \mathrm{kDa} ; \beta$ subunit, highly glycosylated, with a molecular mass of about $50 \mathrm{kDa}$, and $\gamma$ subunit, with a molecular mass of about $15 \mathrm{kDa}(8,14,15)$. The $\alpha$ subunit is responsible for the enzymatic activity. It contains the binding and phosphorylation ATP domain, as well as essential amino acids for the binding of sodium, potassium and some inhibitors $(8,16$, 17). The $\beta$ subunit has a structural function and is important for membrane enzyme insertion $(8,14,18,19)$. The $\gamma$ peptide has hydrophobic characteristics associated with the $\mathrm{Na}, \mathrm{K}-\mathrm{ATPase}$ molecule; however, it is not required for the enzyme catalytic activity or for ion transport. Its association with the $\alpha$ and $\beta$ subunits seems to involve a modulator function for Na,K-ATPase obtained from several tissues (14). In the plasma membranes, the $\alpha$ and $\beta$ subunits build functional oligomers of the $(\alpha \beta)_{2}$ type or oligomers with superior structure $(\alpha \beta)_{\mathrm{n}}(20-24)$. Na,KATPase is specifically inhibited by cardiac glycosides such as ouabain, that bind to the extracellular domains. Its binding and inhibition depend on the combination of magnesium, sodium and potassium ions $(8,25,26)$. Another potent inhibitor of the enzyme is orthovanadate $(25,27)$.

The present study describes the solubilization using only $\mathrm{C}_{12} \mathrm{E}_{8}$, and a single step purification of $\mathrm{Na}, \mathrm{K}-\mathrm{ATPase}$ from the outer medulla of rabbit kidney. Our data suggest that this method is efficient, and the kinetic and structural characteristics of the solubilized enzyme are preserved.

\section{Material and Methods}

All solutions were prepared with Millipore MilliQ ultrapure apyrogenic water. SDS, Tris(hydroxymethyl)aminomethane (Tris), trichloroacetic acid (TCA), 2-N-morpholine 
ethanesulfonic acid (MES), N-(2-hydroxyethyl) piperazine-N'-ethanesulfonic acid (HEPES), 2-amino-2-methyl-propan-1-ol (AMPOL), $\alpha$-naphthyl phosphate, fast blue $\mathrm{RR}$, oligomycin, ouabain, adenosine 5'-triphosphate Tris salt (ATP), sodium orthovanadate, p-nitrophenyl phosphate (di)Tris salt (PNPP), BSA, CHAPS, and 3-((3-cholamidopropyl)dimethylamino)-2-hydroxy-1propane sulfonate (CHAPSO) were from Sigma (St. Louis, MO, USA). Ethylenediaminetetraacetic acid (EDTA), potassium chloride, sodium chloride and magnesium chloride were from Merck (São Paulo, SP, Brazil). $\mathrm{C}_{12} \mathrm{E}_{8}$ was from Calbiochem (San Diego, CA, USA). Analytical grade reagents were used without further purification.

\section{Isolation of $\mathrm{Na}$, K-ATPase from the outer medulla of rabbit kidney}

Isolation of membrane enzyme. Membrane-bound Na,K-ATPase was obtained from the dark red outer medulla of the kidney of adult New Zealand white rabbits as described by Jorgensen (28), with some modifications, as follows. The kidney was removed immediately after sacrifice and stored in ice-cold $20 \mathrm{mM}$ imidazole buffer, pH 6.8, containing $250 \mathrm{mM}$ sucrose, $6 \mathrm{mM}$ EDTA and $6 \mathrm{mM}$ Tris. The kidney was cut into transversal sections and the light gray inner medulla was removed and discarded. The tissue from the dark red outer medulla was obtained by incisions along the inner side of the boundary with the cortex. The extracted tissue was homogenized in 20 $\mathrm{mM}$ imidazole buffer, $\mathrm{pH}$ 6.8, containing $250 \mathrm{mM}$ sucrose, $6 \mathrm{mM}$ EDTA and $6 \mathrm{mM}$ Tris ( $7 \mathrm{ml}$ buffer to $1 \mathrm{~g}$ of moist weight) in a high-speed shearing homogenizer for $30 \mathrm{~s}$. The homogenate was centrifuged at 10,000 $g$ for $35 \mathrm{~min}$ at $4^{\circ} \mathrm{C}$ and the supernatant was ultracentrifuged at $180,000 \mathrm{~g}$ for $1 \mathrm{~h}$ at $4^{\circ} \mathrm{C}$. The pellet corresponding to membranebound $\mathrm{Na}, \mathrm{K}-\mathrm{ATPase}$ was resuspended in $20 \mathrm{mM}$ imidazole buffer, $\mathrm{pH} 6.8$, contain- ing $250 \mathrm{mM}$ sucrose, $6 \mathrm{mM}$ EDTA and 6 $\mathrm{mM}$ Tris, and stored in 1-10 $\mathrm{ml}$ aliquots at $-20^{\circ} \mathrm{C}$.

Solubilization of $\mathrm{Na}, \mathrm{K}$-ATPase membrane fragments with $C_{12} E_{8}$. To determine optimum conditions to solubilize membranebound enzyme, an assay was carried out by varying the protein $/ \mathrm{C}_{12} \mathrm{E}_{8}$ ratio and the time and temperature of incubation with the detergent. Optimum conditions were obtained at $4^{\circ} \mathrm{C}$ after rapid mixing of $1 \mathrm{mg}$ of $\mathrm{Na}, \mathrm{K}-$ ATPase membrane fragments with $1 \mathrm{mg}$ of $\mathrm{C}_{12} \mathrm{E}_{8} / \mathrm{ml}$. The non-solubilized residues were removed by centrifugation at $4^{\circ} \mathrm{C}$ for $1 \mathrm{~h}$ at $100,000 \mathrm{~g}$ in a Hitachi centrifuge. The supernatant was assayed for protein concentration and ATPase and PNPPase activities.

Purification of solubilized Na,K-ATPase. The $\mathrm{C}_{12} \mathrm{E}_{8}$-solubilized enzyme was concentrated through a YM-10 Amicon filter and purified by gel filtration at $4^{\circ} \mathrm{C}$ on a Sepharose $6 \mathrm{~B}$ column $(1.4 \times 119 \mathrm{~cm})$ equilibrated and eluted with $5 \mathrm{mM}$ Tris- $\mathrm{HCl}$ buffer, $\mathrm{pH}$ 7.0, containing $1 \mathrm{mM}$ EDTA, $150 \mathrm{mM} \mathrm{KCl}$ and $0.005 \mathrm{mg} / \mathrm{ml} \mathrm{C}_{12} \mathrm{E}_{8}$ at a flow rate of 21 $\mathrm{ml} / \mathrm{h}$. The fractions showing ATPase activity were pooled, concentrated through a YM-10 Amicon filter, and dialyzed for $2 \mathrm{~h}$ at $4^{\circ} \mathrm{C}$ against $5 \mathrm{mM}$ Tris- $\mathrm{HCl}$ buffer, $\mathrm{pH} 7.5$, containing $15 \mathrm{mM} \mathrm{KCl}, 6 \mathrm{mM}$ EDTA and 0.005 $\mathrm{mg} / \mathrm{ml} \mathrm{C}_{12} \mathrm{E}_{8}$, and stored in 1-ml aliquots at $-20^{\circ} \mathrm{C}$.

\section{Enzyme assay}

PNPPase activity was assayed discontinuously at $37^{\circ} \mathrm{C}$ with a Genesys 2 spectrophotometer by monitoring the liberation of p-nitrophenolate ion $(\varepsilon 1 \mathrm{M}, \mathrm{pH} 13=17,600$ $\left.\mathrm{M}^{-1} \mathrm{~cm}^{-1}\right)$ at $410 \mathrm{~nm}$, in $50 \mathrm{mM}$ HEPES buffer, $\mathrm{pH}$ 7.5, containing $10 \mathrm{mM}$ PNPP, 15 $\mathrm{mM} \mathrm{KCl}$ and $10 \mathrm{mM} \mathrm{MgCl}_{2}$ in a final volume of $1.0 \mathrm{ml}$. The reaction was initiated by the addition of the enzyme and stopped with $1.0 \mathrm{ml}$ of $1 \mathrm{M} \mathrm{NaOH}$. Alternatively, ATPase activity was assayed discontinuously at $37^{\circ} \mathrm{C}$ by quantification of phosphate release as 
described by Santos and Ciancaglini (5), adjusting the assay medium to a final volume of $1.0 \mathrm{ml}$. The reaction was initiated by the addition of the enzyme, stopped with $0.5 \mathrm{ml}$ of cold $30 \%$ TCA at appropriate intervals and centrifuged at $4,000 \mathrm{~g}$ immediately prior to phosphate determination. Standard conditions were $50 \mathrm{mM}$ HEPES buffer, $\mathrm{pH} 7.5$, containing $3 \mathrm{mM} \mathrm{ATP}, 10 \mathrm{mM} \mathrm{KCl}, 5 \mathrm{mM}$ $\mathrm{MgCl}_{2}$ and $50 \mathrm{mM} \mathrm{NaCl}$.

For both enzyme activities the determination was carried out in triplicate and the initial velocities were constant for at least 30 min, provided that less than $5 \%$ of substrate was hydrolyzed. Controls without enzyme were included in each experiment to quantify the non-enzymatic hydrolysis of the substrate. One enzyme unit (U) is defined as the amount of enzyme hydrolyzing $1.0 \mathrm{nmol}$ of substrate per minute at $37^{\circ} \mathrm{C}$.

\section{Protein analysis}

Protein concentrations were estimated as described by Santos and Ciancaglini (5) in the presence of $2 \%(\mathrm{w} / \mathrm{w})$ SDS, with BSA used as standard.

\section{Sucrose density gradient centrifugation of membrane-bound Na,K-ATPase}

Membrane-bound Na,K-ATPase (1 mg) was layered onto a continuous sucrose gradient $(10-50 \%, \mathrm{w} / \mathrm{v})$ in imidazole buffer and centrifuged for $2 \mathrm{~h}$ at $180,000 \mathrm{~g}$ using a Hitachi PV50TA vertical rotor at $4^{\circ} \mathrm{C}$. Fractions of $0.5 \mathrm{ml}$ were collected and assayed for protein concentration (29), refractive index (\% sucrose), and ATPase and PNPPase activities.

\section{Polyacrylamide gel electrophoresis}

Polyacrylamide gel electrophoresis (PAGE) was carried out on 5\% gel according to Davis (30) using silver nitrate for protein staining (31). Phosphohydrolytic activity on the gel was detected in $50 \mathrm{mM}$ HEPES buffer, $\mathrm{pH} 7.5$, containing $10 \mathrm{mM}$ PNPP, 15 $\mathrm{mM} \mathrm{KCl}, 10 \mathrm{mM} \mathrm{MgCl}, 0.12 \%$-naphthyl phosphate, and $0.12 \%$ fast blue RR at $37^{\circ} \mathrm{C}$.

\section{Molecular mass determination}

The molecular mass of the solubilized and purified $\mathrm{Na}, \mathrm{K}-\mathrm{ATPase}$ was estimated by filtration on a Sepharose $6 \mathrm{~B}$ column $(0.8 \mathrm{x}$ $133 \mathrm{~cm}$ ) equilibrated and eluted with $5 \mathrm{mM}$ Tris- $\mathrm{HCl}$ buffer, $\mathrm{pH}$ 7.0, containing $1 \mathrm{mM}$ EDTA, $150 \mathrm{mM} \mathrm{KCl}$ and $0.005 \mathrm{mg} / \mathrm{ml} \mathrm{C}_{12} \mathrm{E}_{8}$. BSA (66 kDa), alcohol dehydrogenase (150 $\mathrm{kDa}), 3$-amylase (200 kDa), apoferritin monomer (110 kDa), apoferritin dimer (221 kDa) and apoferritin tetramer $(443 \mathrm{kDa})$ were used as molecular markers.

The molecular mass of the $\alpha$ and $\beta$ units of kidney $\mathrm{Na}, \mathrm{K}-\mathrm{ATPase}$ was estimated by SDS-PAGE on $10 \%$ gels according to Laemmli (32), using silver nitrate for protein staining (31). Myosin (205 kDa), ß-galactosidase (116 kDa), phosphorylase B (97.4 $\mathrm{kDa})$, BSA (66 kDa), egg albumin (45 kDa) and carbonic anhydrase $(29 \mathrm{kDa})$ were used as molecular markers.

\section{pH sensitivity of catalysis}

The effect of $\mathrm{pH}$ on ATPase and PNPPase activities was measured in $50 \mathrm{mM}$ buffer over the $\mathrm{pH}$ range of 5.0 to 9.5. MES buffer was used in the 5.0 to 6.0 range, Bis-Tris in the 6.0 to 6.5 range, imidazole in the 6.5 to 7.5 range, Tris in the 7.0 to 9.0 range, and AMPOL in the 8.5 to 9.5 range. The $\mathrm{pH}$ of the reaction mixture was measured both before and after the assay and did not vary by more than 0.05 units. ATPase and PNPPase activities were assayed as described above.

\section{Estimation of kinetic parameters}

Maximum velocity $(V)$, initial velocity $(v)$, apparent dissociation constant $\left(K_{0.5}\right)$ and Hill coefficient $(n)$, obtained from sub- 
strate hydrolysis, were determined with a microcomputer program as described by Leone et al. (33). Data are reported as the mean of triplicate determinations in which $\mathrm{P}<0.05$ was considered to be statistically significant.

\section{Results}

Membrane fractions rich in Na,K-ATPase were obtained by homogenization of the dark red outer medulla of the kidney without the addition of SDS. Figure 1 shows the results of the centrifugation of the membrane enzyme in a 10 to $50 \%$ continuous sucrose gradient. A single protein peak, presenting PNPPase and ATPase activities, was obtained between 35.5 and $41 \%$ sucrose.

In order to obtain efficient solubilization of $\mathrm{Na}, \mathrm{K}$-ATPase using only $\mathrm{C}_{12} \mathrm{E}_{8}$, the effects of detergent concentration, protein concentration and incubation time were studied. Figure 2 illustrates the variation in protein concentration for a fixed $\mathrm{C}_{12} \mathrm{E}_{8}$ concentration. The amount of solubilized enzyme increased proportionally, reaching a maximum at a $1 \mathrm{mg}$ protein $/ 1 \mathrm{mg}$ detergent ratio. At protein detergent ratios $>1.0$ ATPase activity in the supernatant decreased, suggesting that the detergent was not sufficient to solubilize a larger amount of enzyme.

Variation of $\mathrm{C}_{12} \mathrm{E}_{8}$ concentration for a fixed protein concentration in the solubilization of membrane Na,K-ATPase (Figure 3) showed that the amount of solubilized enzyme was maximum (about 98\%) when $\mathrm{C}_{12} \mathrm{E}_{8}$ was used at a ratio of $1 \mathrm{mg}$ protein $/ 1 \mathrm{mg}$ detergent. Above this maximum value, the ATPase activity of the solubilized enzyme decreased, but the amount of solubilized protein for $\mathrm{C}_{12} \mathrm{E}_{8}$ concentrations above 1 $\mathrm{mg} / \mathrm{ml}$ remained constant (Figure 3 ). This decrease in ATPase activity can be interpreted as inactivation by excess detergent. Under these conditions, the ATPase activity of solubilized enzyme was similar to that detected for the membrane fraction, with

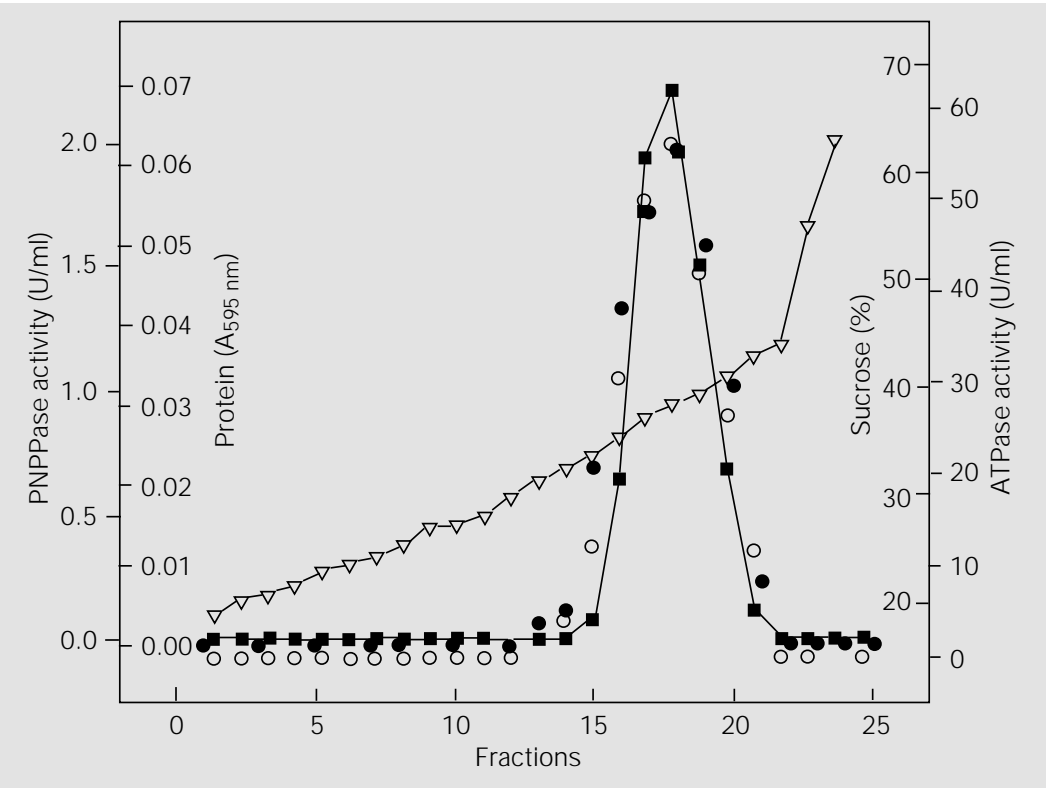

Figure 1. Sucrose density gradient centrifugation of membrane-bound Na,K-ATPase from rabbit kidney outer medulla. A sample of $1.0 \mathrm{mg}$ protein in $20 \mathrm{mM}$ imidazole buffer, $\mathrm{pH} 6.8$, containing 250 $\mathrm{mM}$ sucrose, $6 \mathrm{mM}$ Tris and $6 \mathrm{mM}$ EDTA was layered on a continuous sucrose density gradient (10$50 \%, \mathrm{w} / \mathrm{v}$ ) in $20 \mathrm{mM}$ imidazole buffer, $\mathrm{pH} 6.8$, and centrifuged at 180,000 $\mathrm{g}$ for $2 \mathrm{~h}$ using a Hitachi (Model 55P-72) centrifuge with a vertical rotor (PV50TA), at $4^{\circ} \mathrm{C}$. Fractions of $0.5 \mathrm{ml}$ were collected and assayed for protein concentration (A595 nm; filled circles); refractive index (\% sucrose; triangles); PNPPase activity (squares) and ATPase activity (open circles). ATPase, adenosine 5'-triphosphatase; PNPPase, p-nitrophenyl phosphatase.

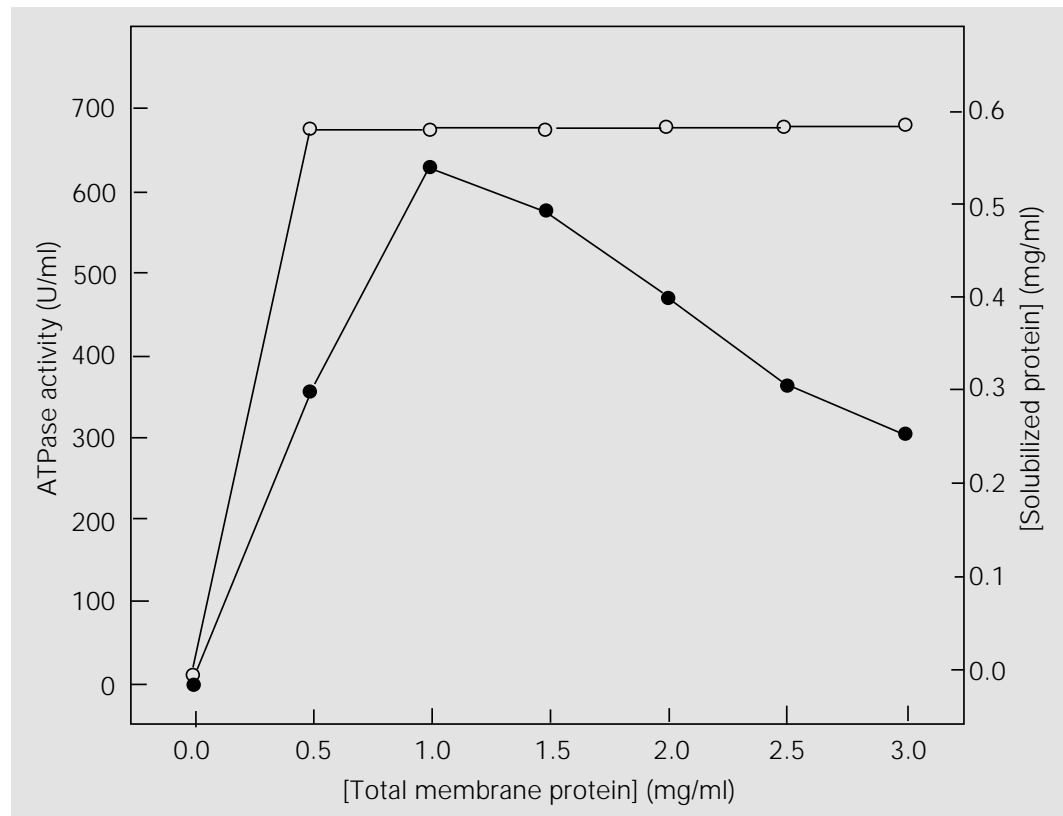

Figure 2. Solubilization of membrane-bound $\mathrm{Na}$,K-ATPase with $1 \mathrm{mg} / \mathrm{ml} \mathrm{C}_{12} \mathrm{E}_{8}$. Aliquots containing different concentrations of membrane-bound $\mathrm{Na}, \mathrm{K}-\mathrm{ATP}$ ase in $20 \mathrm{mM}$ imidazole buffer, $\mathrm{pH} 6.8$, containing $250 \mathrm{mM}$ sucrose, $6 \mathrm{mM}$ Tris and $6 \mathrm{mM}$ EDTA were mixed at $4^{\circ} \mathrm{C}$ with $1 \mathrm{mg} / \mathrm{ml} \mathrm{C}_{12} \mathrm{E}_{8}$ and centrifuged for $1.5 \mathrm{~h}$ at 100,000 g using a Hitachi (Model 55P-72) centrifuge. The supernatant was assayed for ATPase activity (filled circles) and solubilized protein (open circles). ATPase, adenosine $5^{\prime}$-triphosphatase. 
values of about $600-700 \mathrm{U} / \mathrm{mg}$. Solubilization of $\mathrm{Na}, \mathrm{K}-\mathrm{ATPase}$ using $\mathrm{C}_{12} \mathrm{E}_{8}$ at the $1: 1$ ratio $(\mathrm{w} / \mathrm{w})$ was instantaneous and this pro-

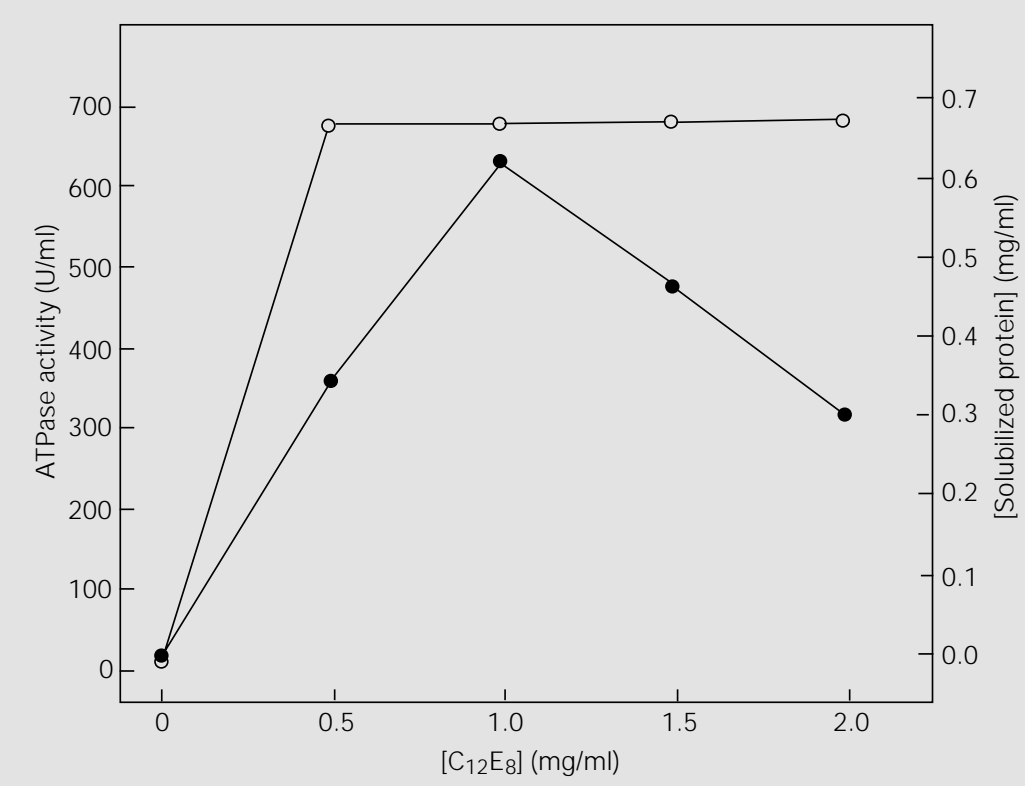

Figure 3. Effect of $\mathrm{C}_{12} \mathrm{E}_{8}$ concentration on the solubilization of membrane-bound $\mathrm{Na}, \mathrm{K}$ ATPase. Aliquots containing $1 \mathrm{mg}$ of membrane-bound Na,K-ATPase in $20 \mathrm{mM}$ imidazole buffer, pH 6.8, containing $250 \mathrm{mM}$ sucrose, $6 \mathrm{mM}$ Tris and $6 \mathrm{mM}$ EDTA were mixed at $4^{\circ} \mathrm{C}$ with $\mathrm{C}_{12} \mathrm{E}_{8}$ at different concentrations and centrifuged for $1.5 \mathrm{~h}$ at $100,000 \mathrm{~g}$ using a Hitachi (Model 55P-72) centrifuge. The supernatant was assayed for ATPase activity (filled circles) and solubilized protein (open circles). ATPase, adenosine $5^{\prime}$-triphosphatase; $\mathrm{C}_{12} \mathrm{E}_{8}$, dodecyloctaethyleneglycol.

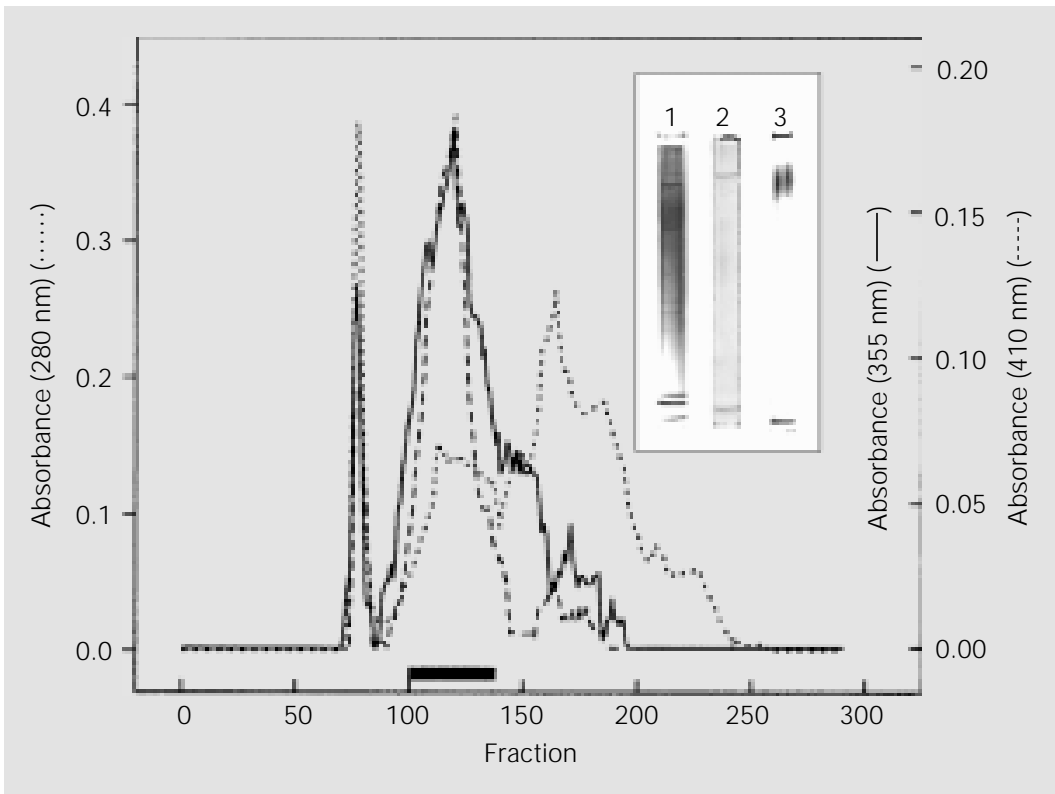

cess was more efficient at $4^{\circ} \mathrm{C}$ (data not shown).

$\mathrm{C}_{12} \mathrm{E}_{8}$-solubilized Na,K-ATPase (1 mg of protein $/ 1 \mathrm{mg}$ of detergent) was purified through a Sepharose 6B column $(1.4 \times 119$ $\mathrm{cm})$. The chromatogram obtained presented at least four protein peaks (Figure 4), and at least two peaks presented as much ATPase as PNPPase activity. Fractions 100-138 obtained in peak 11 were pooled, concentrated, analyzed and found to correspond to solubilized and purified Na,K-ATPase. Moreover, this pool presented a specific activity of 930 $\mathrm{U} / \mathrm{mg}$, with a recovery of about $21.4 \%$ of the total activity present in the outer medulla extract. The protein recovery corresponding to this peak represented about $27.5 \%$ of the total protein applied to the column, $17.4 \%$ of a membrane fragment and only $1.8 \%$ of the total protein present in the outer medulla extract. The purification factor for these purification steps of Na,K-ATPase was about 11.8 (see Table 1).

Non-denaturing PAGE showed that the solubilized extract presented a relatively large number of protein bands. In contrast, the purified sample presented only one discrete

Figure 4. Chromatography of Na,K-ATPase solubilized with $\mathrm{C}_{12} \mathrm{E}_{8}$ on a Sepharose $6 \mathrm{~B}$ column. A sample of $\mathrm{Na}, \mathrm{K}-\mathrm{ATP}$ ase solubilized with $\mathrm{C}_{12} \mathrm{E}_{8}(1: 1, \mathrm{w} / \mathrm{w})$ containing $154 \mathrm{U} / \mathrm{mg}$ was applied to a Sepharose $6 \mathrm{~B}$ column $(1.4 \times 119 \mathrm{~cm})$ equilibrated and eluted with $5 \mathrm{mM}$ Tris$\mathrm{HCl}$ buffer, $\mathrm{pH}$ 7.0, containing $1.0 \mathrm{mM}$ EDTA, $150 \mathrm{mM}$ $\mathrm{KCl}$ and $0.005 \mathrm{mg} / \mathrm{ml} \mathrm{C}_{12} \mathrm{E}_{8}$, at a flow rate of $21 \mathrm{ml} / \mathrm{h}$. Fractions of $3.5 \mathrm{ml}$ were collected and aliquots were assayed for protein concentration (dotted line) $\left(A_{280} \mathrm{~nm}\right)$; PNPPase activity (broken line) and ATPase activity (solid line). The fractions indicated (peak II) were pooled and correspond to solubilized and purified $\mathrm{Na}, \mathrm{K}$ ATPase. Inset: Non-denaturing polyacrylamide gel electrophoresis of $\mathrm{Na}$, K-ATPase in different purification steps: gel $1-\mathrm{C}_{12} \mathrm{E}_{8}$-solubilized extract stained with silver nitrate; gel 2 - purified enzyme (peak II) stained with silver nitrate, and gel 3 - phosphohydrolytic activity of purified enzyme developed with $0.12 \%(\mathrm{w} / \mathrm{v})$ 1-naphthyl phosphate and $0.12 \%(w / v)$ fast blue RR, in the normal kinetic assay medium. 
band with relatively diffuse phosphomonohydrolase activity (Figure 4, inset). These results indicate that the solubilized sample was relatively homogeneous and purified after chromatography through a Sepharose 6B column.

The molecular mass of $\mathrm{C}_{12} \mathrm{E}_{8}$-solubilized and purified $\mathrm{Na}, \mathrm{K}$-ATPase determined by chromatography was about $320 \mathrm{kDa}$ (Figure $5)$. Note that the molecular mass was not corrected for the amounts of phospholipids and detergent that remained bound to the purified enzyme.

In order to determine the integrity of $\mathrm{C}_{12} \mathrm{E}_{8}$-solubilized and purified $\mathrm{Na}, \mathrm{K}$-ATPase, some kinetic studies were performed. Figure 6 shows the pH effect of ATP and PNPP hydrolysis by purified Na,K-ATPase. The same optimum $\mathrm{pH}$ of about 7.5 was found for both substrates. Table 2 shows the effects of some inhibitors on the ATPase and PNPPase activities of purified Na,K-ATPase. It should be stressed that $5 \mathrm{mM}$ ouabain or 3 $\mu \mathrm{M}$ vanadate totally inhibited both assayed activities. Oligomycin $(10 \mu \mathrm{g} / \mathrm{ml})$ and sodium azide $(0.1 \mathrm{mM})$ inhibited activity by about 70 and $15 \%$, respectively. Note that 10 $\mu \mathrm{M}$ ouabain inhibited $\mathrm{Na}, \mathrm{K}-\mathrm{ATPa}$ a activity by $50 \%$ (results not shown).

The results reported for $\mathrm{pH}$ optimum (Figure 6) and inhibition studies (Table 2) attest to the purity of the enzyme using these solubilization and purification steps.

The dependence on ATP concentration of the rate of hydrolysis by purified $\mathrm{Na}, \mathrm{K}$ ATPase at $\mathrm{pH} 7.5$ is shown in Figure 7. Relatively complex results suggested that at least two classes of hydrolyzing sites were involved in these experimental conditions. The high-affinity sites appearing in the range of $1 \mu \mathrm{M}$ to $0.1 \mathrm{mM}$ ATP correspond to about $15 \%$ of total activity $\left(K_{0.5}=4 \mu \mathrm{M}\right.$ and $V=$ $120.9 \mathrm{U} / \mathrm{mg}$ ) while the low-affinity sites observed above $0.1 \mathrm{mM}$ ATP represent $85 \%$ of total activity $\left(K_{0.5}=1.4 \mathrm{mM}\right.$ and $V=703.9$ $\mathrm{U} / \mathrm{mg}$ ). Cooperative effects were found for both hydrolysis sites (0.8 and 0.9 , respec- tively) and inhibition of ATPase activity was observed for ATP concentrations above 3 $\mathrm{mM}$ (results not shown).

The dependence on PNPP concentration

Table 1. Extraction, $\mathrm{C}_{12} \mathrm{E}_{8}$ solubilization and purification steps of an $\mathrm{Na}$, K-ATPase from rabbit kidney outer medulla.

\begin{tabular}{|c|c|c|c|c|c|c|}
\hline Step & $\begin{array}{l}\text { Volume } \\
\text { (ml) }\end{array}$ & $\begin{array}{l}\text { Protein } \\
(\mathrm{mg} / \mathrm{ml})\end{array}$ & $\mathrm{U} / \mathrm{ml}$ & $\mathrm{U} / \mathrm{mg}$ & $\begin{array}{l}\text { Yield } \\
(\%)\end{array}$ & Purification \\
\hline Outer medulla extract & 63 & 11.30 & 890.4 & 78.8 & 100 & 1 \\
\hline Membrane fragment & 53 & 1.40 & 702.9 & 689.2 & 66.4 & 7.5 \\
\hline $\begin{array}{l}\text { Supernatant of solubilized } \\
\text { membrane }\end{array}$ & 64 & 0.893 & 409.1 & 458.1 & 46.7 & 5.8 \\
\hline $\begin{array}{l}\text { Pellet of solubilized } \\
\text { membrane }\end{array}$ & 74.2 & 0.501 & 154.1 & 307.4 & 20.3 & 3.9 \\
\hline $\begin{array}{l}\text { Concentrate of solubilized } \\
\text { extract }\end{array}$ & 35 & 1.34 & 382.9 & 285.8 & 23.9 & 3.6 \\
\hline *Peak II & 85 & 0.152 & 141.4 & 930.3 & 21.4 & 11.8 \\
\hline
\end{tabular}

All assays were carried out in $50 \mathrm{mM}$ HEPES buffer, $\mathrm{pH}$ 7.5, containing $3 \mathrm{mM}$ ATP, 10 $\mathrm{mM} \mathrm{KCl}, 5 \mathrm{mM} \mathrm{MgCl} 2$ and $50 \mathrm{mM} \mathrm{NaCl}$, at $37^{\circ} \mathrm{C}$, as described in Methods. *Peak of a Sepharose 6B column.

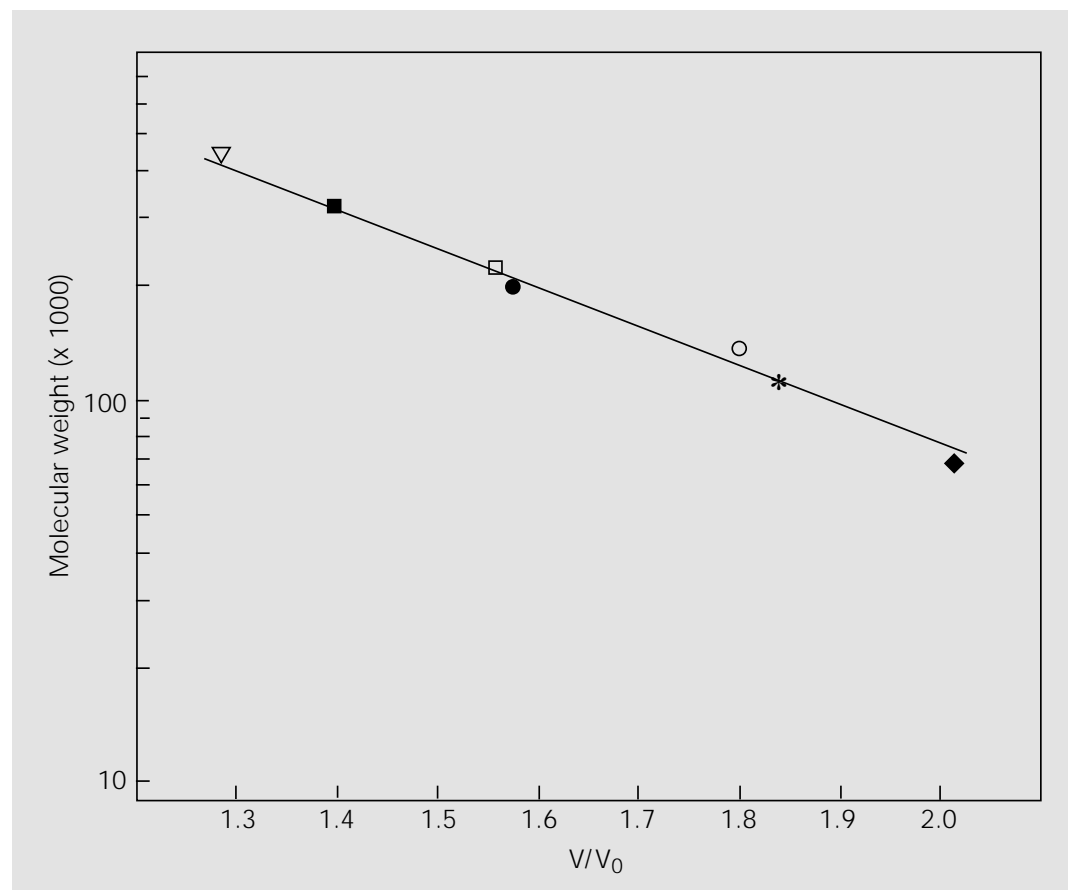

Figure 5. Molecular mass determination of $\mathrm{C}_{12} \mathrm{E}_{8}$-solubilized Na,K-ATPase. Molecular mass was determined using a Sepharose $6 \mathrm{~B}$ column $(0.8 \times 133 \mathrm{~cm})$ equilibrated and eluted with 5 $\mathrm{mM}$ Tris-HCl buffer, $\mathrm{pH} 7.0$, containing $1 \mathrm{mM}$ EDTA, $150 \mathrm{mM} \mathrm{KCl}$ and $0.005 \mathrm{mg} / \mathrm{ml} \mathrm{C}_{12} \mathrm{E}_{8}$ as described in Material and Methods. BSA (lozenge); alcohol dehydrogenase (open circle); ßamylase (filled circle); apoferritin tetramer (triangle); apoferritin dimer (open square); apoferritin monomer (asterisk), and solubilized and purified Na,K-ATPase (filled square). 
of the rate of hydrolysis by purified $\mathrm{Na}$, $\mathrm{K}$-ATPase at $\mathrm{pH} 7.5$ in the presence of $10 \mathrm{mM} \mathrm{MgCl}_{2}$ and $15 \mathrm{mM} \mathrm{KCl}$ showed a single saturation curve with cooperative effects $(n=1.3), K_{0.5}=0.74 \mathrm{mM}$ and

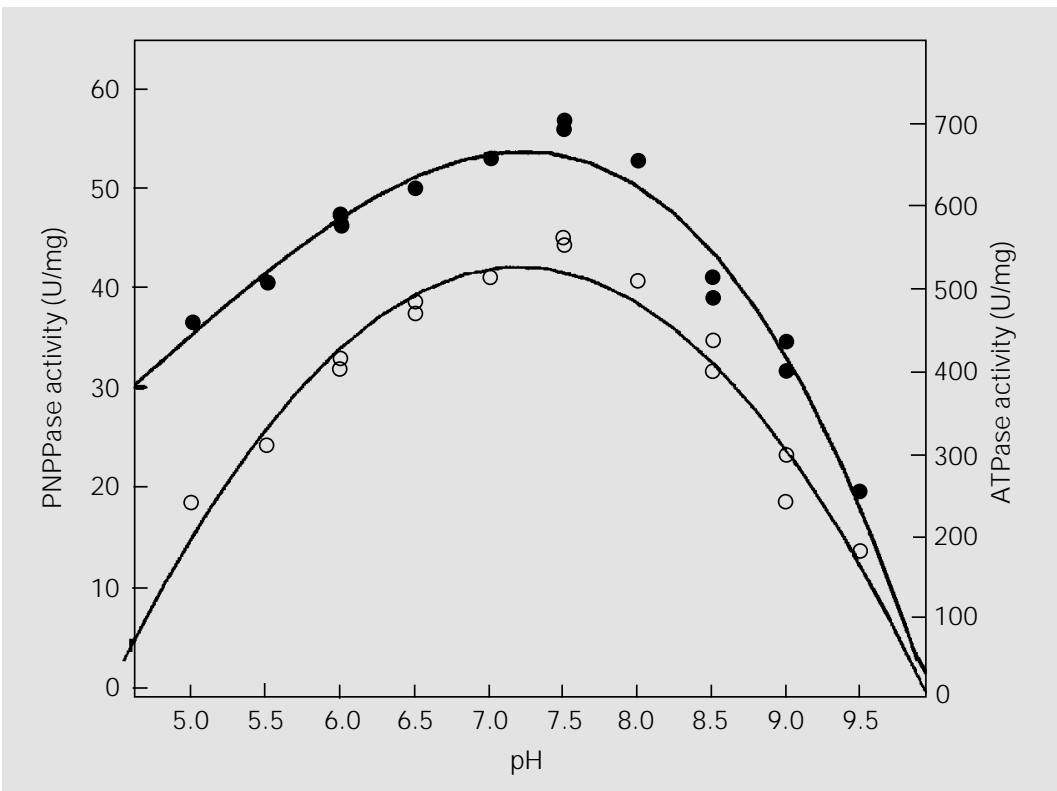

Figure 6. $\mathrm{pH}$ sensitivity of the hydrolysis of p-nitrophenyl phosphate (PNPP) and adenosine 5'-triphosphate (ATP) by Na,K-ATPase solubilized with $\mathrm{C}_{12} \mathrm{E}_{8}(1: 1, \mathrm{w} / \mathrm{w})$ and purified on a Sepharose 6B column. PNPPase (filled circles) and ATPase activities (open circles) are shown. Assays were buffered with $50 \mathrm{mM}$ buffer containing $5 \mathrm{mM} \mathrm{MgCl} 2,10 \mathrm{mM} \mathrm{KCl}$ and $50 \mathrm{mM} \mathrm{NaCl}$ and the substrate, i.e., $10 \mathrm{mM}$ PNPP or $3 \mathrm{mM}$ ATP (for details, see Material and Methods). The reaction was started by the addition of $3.5 \mu \mathrm{g}$ protein.

Table 2. Effect of several inhibitors on adenosine 5'-triphosphatase (ATPase) and p-nitrophenyl phosphatase (PNPPase) activities of purified Na,K-ATPase from rabbit kidney outer medulla.

\begin{tabular}{lccc}
\hline Inhibitors & Concentration & \multicolumn{2}{c}{ Inhibition (\%) } \\
\cline { 3 - 4 } & & ATPase & PNPPase \\
\hline Ouabain & $5 \mathrm{mM}$ & 99.1 & 99.9 \\
Oligomycin & $1 \mu \mathrm{g} / \mathrm{ml}$ & 81.1 & 63.7 \\
Sodium azide & $100 \mu \mathrm{M}$ & 14.5 & 16.1 \\
Vanadate & $3 \mu \mathrm{M}$ & 98.5 & 93.2 \\
\hline
\end{tabular}

All assays were carried at $37^{\circ} \mathrm{C}$ as described in Methods. ATPase activity was assayed in $50 \mathrm{mM}$ HEPES buffer, $\mathrm{pH} 7.5$, containing $3 \mathrm{mM}$ ATP, $10 \mathrm{mM} \mathrm{KCl}, 5 \mathrm{mM} \mathrm{MgCl} 2$ and $50 \mathrm{mM} \mathrm{NaCl}$, using $10 \mu \mathrm{g}$ of enzyme. Specific activity of $100 \%$ corresponds to $603.2 \mathrm{U} /$ mg. PNPPase activity was assayed in $50 \mathrm{mM}$ HEPES buffer, pH 7.5, containing $10 \mathrm{mM}$ PNPP, $15 \mathrm{mM} \mathrm{KCl}$ and $10 \mathrm{mM} \mathrm{MgCl}$, using $10 \mu$ of enzyme. Specific activity of $100 \%$ corresponds to $38.5 \mathrm{U} / \mathrm{mg}$.
$V=42.1 \mathrm{U} / \mathrm{mg}$ (results not shown).

\section{Discussion}

Obtaining Na,K-ATPase from a highly specialized tissue with enhanced capacity for $\mathrm{Na}^{+}$and $\mathrm{K}^{+}$transport such as the outer medulla of the kidney has the advantage of obtaining enzyme activity in relatively large amounts $(7,8,28)$.

Generally, Na,K-ATPase-rich membranes were obtained by mechanical tissue disruption followed by differential centrifugation steps. However, other methods, such as cloning techniques using the enzyme expressed in different systems, have also been described and used for enzyme production and characterization $(14,34)$.

Kidney outer medulla membrane extraction and homogenization followed by a sucrose gradient resulted in a single protein peak (Figure 1). The fact of not finding any other soluble protein component along the whole gradient suggests that the membrane obtained in the preparation of $\mathrm{Na}, \mathrm{K}-\mathrm{ATPase}$ was homogeneous. However, it should be emphasized that membranes contain many proteins and solubilization and purification methods are necessary for isolation of the pure $\mathrm{Na}, \mathrm{K}$-ATPase enzyme $(8,19,25,35)$. The presence of other enzymes in the membrane fraction was easily proven by specific inhibitors such as ouabain. In fact, $5 \mathrm{mM}$ ouabain inhibited only $11.5 \%$ of the ATPase activity of the membrane fraction (data not shown).

Therefore, Na,K-ATPase could be separated from the other proteins present in the membrane that can directly or indirectly interfere with the kinetic properties of the enzyme. The development of a rational approach to the solubilization of membrane proteins always requires a review of the literature to determine the detergent type and the conditions that are generally used for the solubilization of the protein of interest $(1,3$ $8,10)$. 
The treatment of Na,K-ATPase membrane fractions with different concentrations of SDS resulted in a time-dependent inactivation of the enzyme activity (5). This inactivation is also determined by the SDS/protein ratio. Moreover, apparently many SDS molecules are involved in the inactivation of a single Na,K-ATPase molecule. The use of SDS is only recommended for the selective removal of some contaminant proteins of the membrane without significantly affecting the $\mathrm{Na}, \mathrm{K}$-ATPase molecule, which remains in the membrane fraction after this treatment (28).

The incubation of the Na,K-ATPase-rich membrane fraction with SDS is also recommended in the presence of ATP because this substrate protects the enzyme structure against inactivation. Another important factor is that the purification procedure using SDS should be combined with density gradient centrifugation steps. This slow purification procedure resulted in a significant loss and irreversible inactivation of ATPase activity, even when controlling the detergent/ protein relationship, temperature, $\mathrm{pH}$, incubation time and buffer ionic forces $(7,28)$.

Our method using only $\mathrm{C}_{12} \mathrm{E}_{8}$ is based on the methodology described by Santos and Ciancaglini (5) and others who used it combined with other detergents $(7,10)$. The advantage of this method is the considerable reduction in the time needed to obtain the purified enzyme, which is solubilized instantaneously and purified in a single chromatographic step and has a smaller denaturing effect on the solubilized enzyme.

The amount of solubilized enzyme activity was maximum, about $98 \%$, when $\mathrm{C}_{12} \mathrm{E}_{8}$ was used at a ratio of $1 \mathrm{mg}$ enzyme $/ 1 \mathrm{mg}$ detergent (Figures 2 and 3). Under these conditions, the specific ATPase activity of the solubilized $\mathrm{Na}, \mathrm{K}-\mathrm{ATPase}$ was in the range of $600-700 \mathrm{U} / \mathrm{mg}$, which is similar to the activity of the membrane enzyme, as reported by Cornelius (7) for the enzyme obtained from rabbit kidney. However, activi- ties 20-30-fold higher have been reported both for membrane-bound and solubilized enzyme $(8,10,28)$. In our study the initial activity for the membrane-bound enzyme was lower than reported by others but a purification factor of about 6-10-fold, which is typical for enzyme isolated from membrane of specialized tissue, suggests a selective extraction of $\mathrm{Na}, \mathrm{K}-\mathrm{ATPase}$.

It should be noted that quite different values of specific ATPase activity can be obtained in different conditions for tissue source, solubilization and purification, as well as methods for the determination of enzymatic activity $(4,5,7,10,36)$.

The enzyme obtained from the kidney external medulla showed a purification factor of about 11 (Figure 4 and Table 1). In a single chromatographic step, rabbit kidney $(\alpha \beta)_{2}$ protomer of $\mathrm{Na}, \mathrm{K}-\mathrm{ATPase}$ was purified and separated from non-solubilized pro-

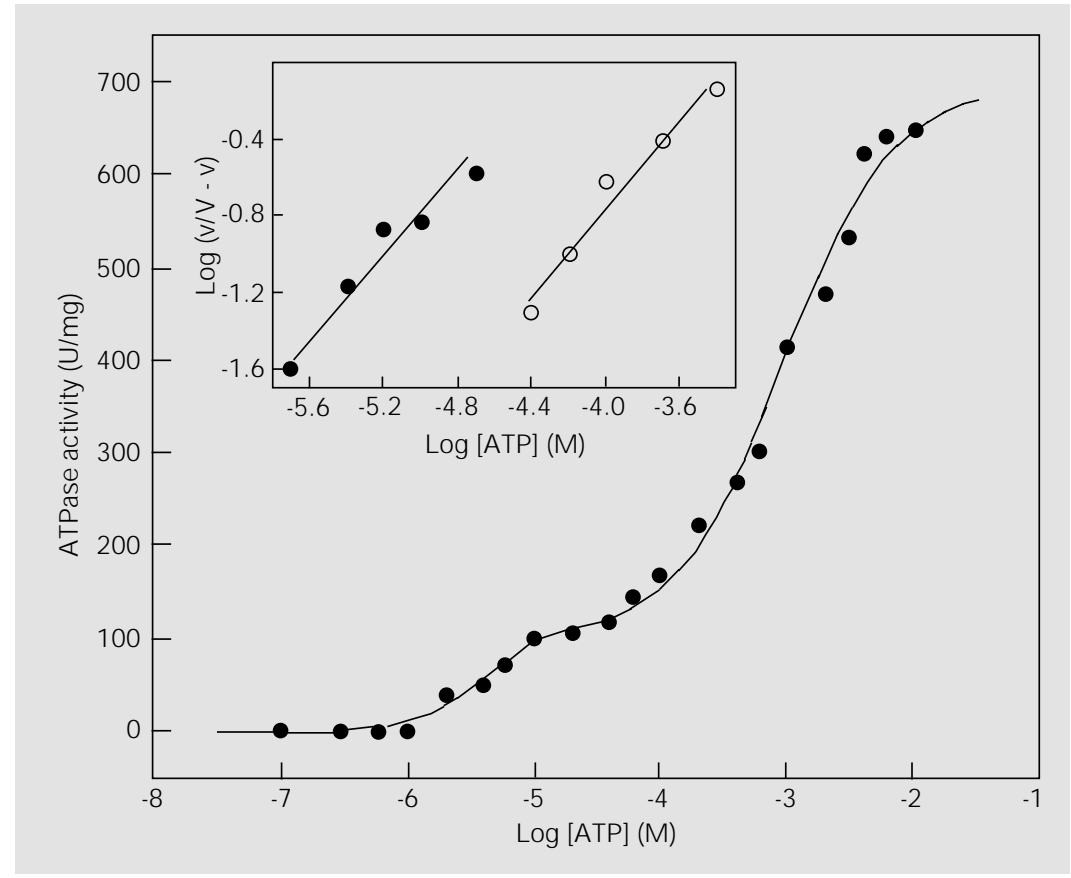

Figure 7. Effect of adenosine 5 '-triphosphate (ATP) concentration on ATPase activity of $\mathrm{Na}, \mathrm{K}-\mathrm{ATP}$ ase solubilized with $\mathrm{C}_{12} \mathrm{E}_{8}(1: 1, \mathrm{w} / \mathrm{w})$ and purified on a Sepharose $6 \mathrm{~B}$ column. Assays were buffered with $50 \mathrm{mM}$ HEPES buffer, pH 7.5, containing ATP, $5 \mathrm{mM} \mathrm{MgCl}, 10$ $\mathrm{mM} \mathrm{KCl}$ and $50 \mathrm{mM} \mathrm{NaCl}$. The reaction was started by the addition of $3.5 \mu \mathrm{g}$ protein. Inset: Hill plot for the respective results: high-affinity sites (filled circles) and low-affinity sites (open circles). 
teins that were excluded in the column "void", and other proteins that were also solubilized by the detergent, and from different other forms of association between the $\alpha$ and $\beta$ subunits and even the individual subunits $(10,28)$. The purification factor, the specific activity and the stability of the enzyme solubilized and purified by gel filtration obtained by several authors with $\mathrm{Na}$,K-ATPases from different sources show different values. This fact can be attributed to several causes, including i) variation in the methodology for the extraction and preparation of the membrane fraction; ii) differences in the determination of activity such as different substrate concentrations, buffer, and metal ion used at different concentrations, and iii) differences in the duration and in the temperature of the solubilization and purification steps $(7,10$, 28).

In the present study the molecular mass found for rabbit kidney Na,K-ATPase solubilized with $\mathrm{C}_{12} \mathrm{E}_{8}$ and purified on a Sepharose $6 \mathrm{~B}$ column was about $320 \mathrm{kDa}$ (Figure $5)$, suggesting an association of the $(\alpha \beta)_{2}$ type, considering the molecular mass of the $\alpha$ and $\beta$ subunits to be about 100 and $57 \mathrm{kDa}$, respectively. Note that, under our experimental conditions, amounts of phospholipids and detergent that remained bound to the purified enzyme were not taken into account. Moreover, when the purification step used 10-fold more detergent, a significant decrease in the activity of the fractions corresponding to the oligomer $(\alpha \beta)_{2}$ was observed (results not shown). Another important factor which may be responsible for the loss of catalytic activity of the enzyme can be attributed to the oligomer delipidation that might occur in the presence of high detergent concentrations $(7,10)$.

Although most of the structural studies indicate a $1: 1$ stoichiometry of the $\alpha$ and $\beta$ subunits, the exact quaternary structure of $\mathrm{Na}, \mathrm{K}-\mathrm{ATPase}$, as well as its functional association with the membrane, are not understood. There are controversies about whether the enzyme exists as a protomer $(\alpha \beta)(21$ $23,37)$ or as a diprotomer $(\alpha \beta)_{2}$ involving a balance between protomer-diprotomer, or even in the form of oligomers $(\alpha \beta)_{n}(24,38)$.

Rabbit kidney Na,K-ATPase, when solubilized with $\mathrm{C}_{12} \mathrm{E}_{8}$, and purified by fractionated centrifugation, showed that the solubilized form of the enzyme consists predominantly (80-85\%) of associations of the $(\alpha \beta)$ type, with molecular mass between 140 and $170 \mathrm{kDa}(7,20-22,28)$. However, when other isolation methods are used, such as gel filtration, a relatively stable association of subunit $(\alpha \beta)_{2}$ types and/or superior oligomers with molecular mass of $257-380 \mathrm{kDa}$ was observed. It is important to note that these associations are necessary for the enzyme to have a catalytic activity and are related to the incubation time with the detergent and to detergent concentration $(10,20-22,24)$.

The apparent optimum $\mathrm{pH}$ for ATP and PNPP hydrolysis by Na,K-ATPase (Figure 6) was 7.5 for the same substrate, and was similar to that reported by other investigators with enzymes obtained from several tissues (28). The effect of some Na,K-ATPase inhibitors showed that the solubilized enzyme is completely inhibited by $5 \mathrm{mM}$ ouabain or $3 \mu \mathrm{M}$ vanadate (see Table 2), as described by several authors $(8,13,19,25)$. However, oligomycin does not completely inhibit the activity of $\mathrm{Na}, \mathrm{K}-\mathrm{ATPase}(80 \%)$, and it is known that the effect of this inhibitor depends on the enzyme orientation and the presence of sodium ions $(8,13,25)$.

Finally, the inhibition of only about $15 \%$ of Na,K-ATPase by sodium azide confirmed the absence of FoF1-ATPase (25). It is important to emphasize that the effect of these inhibitors depends on the presence of divalent metal ions (sodium, potassium and/or magnesium) and the substrate used in the reaction medium, as well as on the tissue origin of $\mathrm{Na}, \mathrm{K}$-ATPase $(8,25)$.

Kinetic results for $\mathrm{C}_{12} \mathrm{E}_{8}$-solubilized and purified $\mathrm{Na}, \mathrm{K}-\mathrm{ATPase}$ (Figure 7) revealed two classes of ATP-hydrolyzing sites under 
these experimental conditions, one in the micromolar range (high-affinity site) and the other in the millimolar range (low-affinity site), presenting negative cooperativity.

Results using microsomal fractions of several vertebrate tissues showed that the stimulation of Na,K-ATPase activity by ATP occurs through two-phase curves, one with $K_{0.5}$ from 0.1 to $1 \mu \mathrm{M}$ and the other with $K_{0.5}$ from 0.01 to $0.4 \mathrm{mM}$, which suggests the existence of two sites of substrate hydrolysis $(21,39)$. Dual effects were also found on ATP hydrolysis by $\mathrm{C}_{12} \mathrm{E}_{8}$-solubilized and purified Na,K-ATPase with $K_{0.5}$ values of about 0.1 and $4 \mu \mathrm{M}$ for the high-affinity site and of about 0.1 and $0.5 \mathrm{mM}$ for the lowaffinity site, both with negative cooperativity, suggesting that the enzyme environment or oligomer formation is very important for substrate hydrolysis $(21-23,40)$. It should be emphasized that the contribution of the highaffinity site to the ATPase specific activity of the enzyme generally corresponds to values about 1 to $10 \%$ of the total activity, which hinders its kinetic characterization
$(21-23,39)$. It is very difficult to determine whether these arose from the presence of more than one ATP site per $(\alpha \beta)$ protomer or from a single site whose function and affinity change during the catalytic cycle (2124,40 ), and the functional relationship between the two hydrolysis sites and their behavior during the reaction cycle remains to be explored.

The kinetic data shown for rabbit kidney $\mathrm{Na}, \mathrm{K}-\mathrm{ATPase}$ solubilized with $\mathrm{C}_{12} \mathrm{E}_{8}$ and purified suggest that the enzyme molecule is preserved and presents some important characteristics reported by some investigators, i.e., stability, $(\alpha \beta)_{2}$ protomer association, biphasic behavior during ATP hydrolysis, and ouabain and vanadate inhibition, which makes the method suitable for obtaining the enzyme for studies in reconstitution systems.

\section{Acknowledgments}

We thank Dr. Richard John Ward and Mrs. Priscila C. Ciancaglini for revising the manuscript.

\section{References}

1. Helenius A, McCaslin DR, Fries E \& Tanford C (1979). Properties of detergent. Methods in Enzymology, 56: 734-749.

2. Tanford C (1980). The Hydrophobic Effect: Formation of Micelles and Biological Membranes. 2nd edn. Wiley-Interscience, New York, NY, USA.

3. Koepsell H (1986). Methodological aspects of purification and reconstitution of transport proteins from mammalian plasma membranes. Reviews of Physiology, Biochemistry and Pharmacology, 104: 65137.

4. Silvius J R (1992). Solubilization and functional reconstitution of biomembrane components. Annual Review of Biophysics and Biomolecular Structure, 21: 323348.

5. Santos HL \& Ciancaglini P (2000). A practical approach to the choice of a suitable detergent and optimal conditions to solubilize a membrane protein. Biochemical Education, 28: 178-182.
6. Le Maire $M$, Champeil $P \&$ \& Moller JV (2000). Interaction of membrane proteins and lipids with solubilizing detergents. Biochimica et Biophysica Acta, 1508: 86111.

7. Comelius F (1991). Functional reconstitution of the sodium pump. Kinetics of exchange reactions performed by reconstituted Na,K-ATPase. Biochimica et Biophysica Acta, 1071: 19-66.

8. Skou J C \& Esmann M (1992). The (Na+, $\mathrm{K}^{+}$)-ATPase. J ournal of Bioenergetics and Biomembranes, 24: 249-261.

9. J ackson RL, Verkleij AJ , Van Zoelen EJ J , Lane LK, Schwartz A \& Van Deenen LLM (1980). Asymmetric incorporation of $\mathrm{Na}, \mathrm{K}$ ATPase into phospholipid vesicles. Archives of Biochemistry and Biophysics, 200: 269-278.

10. Brotherus J R, J acobsen $L \& J$ orgensen PL (1983). Soluble and enzymatically stable $\mathrm{Na}$,K-ATPase from mammalian kidney consisting predominantly of protomer $\alpha ß$-units. Preparation, assay and reconstitution of active $\mathrm{Na}$, $\mathrm{K}$ transport. Biochimica et Biophysica Acta, 731: 290-303.

11. Esmann M \& Skou J C (1985). Occlusion of $\mathrm{Na}^{+}$by the $\mathrm{Na}$,K-ATPase in the presence of oligomycin. Biochemical and Biophysical Research Communications, 127: 857-863.

12. J orgensen PL (1992). Functional domains of Na,K-ATPase; conformational transitions in the $\alpha$-subunit and ion occlusion. Acta Physiologica Scandinavica, 146: 8994.

13. Skou J C (1998). The identification of the sodium-potassium pump (Nobel Lecture). Angewandte Chemie International Edition, 37: 2320-2328.

14. Pressley TA (1996). Structure and function of the $\mathrm{Na}, \mathrm{K}$ pump: ten years of molecular biology. Mineral and Electrolyte Metabolism, 22: 264-271.

15. J orgensen PL, Nielsen J M, Rasmussen JH \& Pedersen PA (1998). Structure- 
funtion relationships based on ATP binding and cation occlusion at equilibrium in Na,K-ATPase. Acta Physiologica Scandinavica, 163: 79-87.

16. J orgensen PL, Rasmussen J H, Nielsen J M \& Pedersen PA (1997). Transportlinked conformational changes in $\mathrm{Na}$, $\mathrm{K}$ ATPase. Structure-function relationships of ligand binding and E1-E2 conformational transitions. Annals of the New York Academy of Sciences, 834: 161-174.

17. Lingrel J B, Croyle LM, Woo AL \& Arguello J M (1998). Ligand binding sites of $\mathrm{Na}$, KATPase. Acta Physiologica Scandinavica, 163: 69-77.

18. O'Brien WJ, Lingrel JB \& Wallick ET (1994). Ouabain binding kinetics of the rat alpha two and alpha three isoforms of the sodium-potassium adenosine triphosphate. Archives of Biochemistry and Biophysics, 310: 32-39.

19. Emery AM, Billingsley PF, Ready PD \& Djamgoz MBA (1998). Insect $\mathrm{Na}, \mathrm{K}$ ATPase. J ournal of Insect Physiology, 44: 197-209.

20. Brotherus J R, M oller J V \& J orgensen PL (1981). Soluble and active renal $\mathrm{Na}, \mathrm{K}$ ATPase with maximum protein molecular mass $170,000 \pm 9,000$ daltons; formation of larger units by secondary aggregation. Biochemical and Biophysical Research Communications, 100: 146-154.

21. Ward DG \& Cavieres JD (1993). Solubilized $\alpha ß \mathrm{Na}$,K-ATPase remains protomeric during turnover yet shows apparent negative cooperativity toward ATP. Proceedings of the National Academy of Sciences, USA, 96: 5332-5336.

22. Ward DG \& Cavieres J D (1996). Binding of $2^{\prime}\left(3^{\prime}\right)-0-(2,4,6$-trinitrophenyl)ADP to soluble alpha beta protomers of $\mathrm{Na}, \mathrm{K}$ ATPase modified with fluorescein isothiocyanate. Evidence for two distinct sites. J ournal of Biological Chemistry, 271:
12317-12321.

23. Ward DG \& Cavieres J D (1998). Photoinactivation of fluorescein isothiocyanatemodified $\mathrm{Na}$, K-ATPase by 2' (3')-O-(2,4,6trinitrophenyl)8-azidoadenosine $5^{5}$-diphosphate. J ournal of Biological Chemistry, 273: 14277-14284.

24. Linnertz $\mathrm{H}$, Urbanova $\mathrm{P}$, Obsil $\mathrm{T}$, Herman P, Amler E \& Schoner W (1998). Molecular distance measurements reveal an (alpha beta)(2) dimeric structure of $\mathrm{Na}, \mathrm{K}$ ATPase - high affinity ATP binding site and $\mathrm{K}^{+}$-activated phosphatase reside on different alpha-subunits. J ournal of Biological Chemistry, 273: 28813-28821.

25. MacGregor SE \& Walker J M (1993). Inhibitors of the Na,K-ATPase. Comparative Biochemistry and Physiology, 105C: 1-9.

26. Kasturi R, Yuan J , McLean LR, Margolies MN \& Ball WJ (1998). Identification of a model cardiac glycosid receptor: comparisons with $\mathrm{Na}$, K-ATPase. Biochemistry, 37 : 6658-6666.

27. Fedosova NU, Cornelius $F \&$ Klodos I (1998). E2P phosphoforms of $\mathrm{Na}, \mathrm{K}$ ATPase. I. Comparison of phosphointermediates formed from ATP and Pi by their reactivity toward hydroxylamine and vanadate. Biochemistry, 37: 13634-13642.

28. J orgensen PL (1988). Purification of $\mathrm{Na}, \mathrm{K}$ ATPase. Enzyme sources, preparative problems and preparation from mammalian kidney. Methods in Enzymology, 156: 29-42.

29. Read SM \& Northcote DH (1981). Minimization of variation in the response to different proteins of the Coomassie blue $\mathrm{G}$ dye-binding assay for protein. Analytical Biochemistry, 116: 53-64.

30. Davis BJ (1964). Disc electrophoresis II Method and application to human serum proteins. Annals of the New York Academy of Sciences, 121: 404-427.

31. Blum H, Beir H \& Gross HJ (1987). Im- proved silver staining of plant proteins, RNA and DNA in polyacrylamide gels. Electrophoresis, 8: 93-99.

32. Laemmli UK (1970). Cleavage of structural proteins during the assembly of the head of bacteriophage T4. Nature, 227: 680-685.

33. Leone FA, Degreve $L \&$ Baranauskas J A (1992). Sigraf-A versatile computer-program for fitting enzyme kinetic data. Biochemical Education, 20: 94-96.

34. Pedersen PA, Rasmussen J H \& J orgensen PL (1996). Consequences of mutations to the phosphorylation site of the alpha-subunit of Na,K-ATPase for ATP binding and E1-E2 conformational equilibrium. Biochemistry, 35: 16085-16093.

35. Yingst $D R$, Yang $S Y \&$ Schiebinger $R$ (1998). Purification of active Na,K-ATPase using a new ouabain-affinity column. American J ournal of Physiology, 275C: 1167-1177.

36. Rigaud J L, Pitard B \& Levy D (1995). Reconstitution of membrane proteins into liposomes: application to energy-transducing membrane proteins. Biochimica et Biophysica Acta, 1231: 223-246.

37. J orgensen PL \& Andersen JP (1986). Structural basis for E1-E2 conformational transitions in $\mathrm{Na}$, K-pump proteins. J ournal of Membrane Biology, 103: 95-120.

38. Tsuda T, Kaya S, Yokoyama T \& Taniguchi K (1997). Are pyridoxal and fluorescein probes in lysine residues of $\alpha$-chain in $\mathrm{Na}^{+}, \mathrm{K}^{+}-$ATPase sensing ATP binding? Annals of the New York Academy of Sciences, 834: 186-192.

39. Robinson JD (1976). Substrate sites for the $\mathrm{Na}, \mathrm{K}$ dependent ATPase. Biochimica et Biophysica Acta, 429: 1006-1019.

40. Thoenges $D$, Linnetz $H \&$ \& Schoner $W$ (1997). A two-site model of interacting ATP sites. Annals of the New York Academy of Sciences, 834: 322-326. 